\title{
Linking Informal and Formal Electronics Recycling via an Interface Organization
}

\author{
Eric Williams ${ }^{1}{ }^{*}$, Ramzy Kahhat ${ }^{2}$, Magnus Bengtsson ${ }^{3}$, Shiko Hayashi ${ }^{3}$, Yasuhiko Hotta ${ }^{3}$ \\ and Yoshiaki Totoki ${ }^{3}$
}

1 Golisano Institute for Sustainability, Rochester Institute of Technology, Rochester, NY 14623, USA

2 Department of Engineering, Pontificia Universidad Católica del Perú, Lima 32, Peru;

E-Mail: ramzy.kahhat@pucp.pe

3 Institute for Global Environmental Strategies, Hayama, Kanagawa-ken 240-0115, Japan;

E-Mails: bengtsson@iges.or.jp (M.B.); hayashi@iges.or.jp (S.H.); hotta@iges.or.jp (Y.H.); totoki@iges.or.jp (Y.T.)

* Author to whom correspondence should be addressed; E-Mail: exwgis@ rit.edu;

Tel.: +1-585-475-7211.

Received: 26 April 2013; in revised form: 18 June 2013 / Accepted: 11 July 2013 /

Published: 23 July 2013

\begin{abstract}
Informal recycling of electronics in the developing world has emerged as a new global environmental concern. The primary approach to address this problem has been command-and-control policies that ban informal recycling and international trade in electronic scrap. These bans are difficult to enforce and also have negative effects by reducing reuse of electronics, and employment for people in poverty. An alternate approach is to link informal and formal sectors so as to maintain economic activity while mitigating environmental damages. This article explores the idea of an interface organization that purchases components and waste from informal dismantlers and passes them on to formal processors. Environmental, economic and social implications of interface organizations are discussed. The main environmental questions to resolve are what e-scrap components should be targeted by the interface organization, i.e., circuit boards, wires, and/or plastic parts. Economically, when formal recycling is more profitable (e.g., for circuit boards), the interface organization is revenue positive. However, price subsidies are needed for copper wires and residual waste to incentivize informal dismantlers to turn in for formal processing. Socially, the potential for corruption and gaming of the system is critical and needs to be addressed.
\end{abstract}


Keywords: electronics waste; scrap; reuse; informal recycling; circuit boards; economic instruments; environmental impacts; policy

\section{Introduction: Informal Recycling of End-of-Life Electronics: A New Policy Challenge}

Informal recycling of electronics in the developing world has emerged as a new sustainability challenge. Informal recycling, a backyard industry, processes scrap electronics (e-waste) to extract recyclable materials. NGO reports have drawn attention to environmental problems arising from informal recycling in China, India, Africa and elsewhere [1-3]. For example, gold in circuit boards is recovered using hydrometallurgical processes with acids and cyanides, and afterwards dumped into local water systems. Insulation from copper wires is often removed by open burning, a process that emits dioxins, furans and other pollutants. Scientific studies have been carried out in Guiyu in Southern China - the most infamous of informal recycling areas - confirming significant impacts on the environment and human health [4-7].

To set terminology, a word is needed to denote electronics disposed of by its initial user. Sometimes these electronics are refurbished and reused, recycled for materials, or put in landfills. E-waste, short for electronic waste, is the most commonly used term. Used electronics is another possibility. In this article, we use the word e-scrap, as it better, though still imperfectly, encodes the dual product and waste aspects of end-of-first-life electronics.

Mitigating environmental impacts from informal recycling of e-scrap is a new challenge for environmental policy. Thus far, efforts to address the problem have focused on traditional command and control approaches. Much of the material informally recycled in the developing world is thought to come from developed countries. One policy approach to address informal recycling is to ban trade in used and scrap electronics [1]. Trade bans can be pursued at the national level, for instance, as a potential importer. China banned the import of used electronic products, including parts, in 2000 [8]. As a potential exporter, the European Union does not allow any export of e-scrap for processing or disposal in non-OECD countries. At the international level, the Basel Convention is the primary multilateral framework to manage flows in hazardous materials, requiring prior notification of trans-boundary shipments of substances categorized as hazardous, and explicit consent by the receiving country [9]. Note that the Basel Convention exempts products intended for reuse, thus policies restricting imports and exports of used electronics are at the national, not international level.

The second command and control approach to address informal recycling is to outlaw informal processing. The appropriate local or national environmental authorities would need to find and punish informal recyclers through fines or other measures. An example of this approach is China, which banned informal recycling in 2003 [10].

There are a number of concerns regarding trade bans and outlawing informal recycling. The first concern is effectiveness of these policies in practice. Thus far, both types of bans have apparently been ineffective in stopping informal recycling. China has laws of both types on the books but they are loosely enforced, and informal recycling in China apparently continues much the same as before legislation [11,12]. Despite a Europe-wide ban on exportation of e-scrap, anecdotal evidence suggests widespread violations [13]. Presumably, the main reasons for this failure are insufficient enforcement, 
inability and/or unwillingness to disrupt large container port operations, and continuing profitability of trade in e-scrap. Increasing resource prices seen in recent years make recycling more profitable, therefore encouraging informal recycling as well. Another factor is that banning the informal recycling sector can make it a target for the involvement of organized crime [12]. A poorly enforced ban on informal recycling could thus be worse than no ban at all.

A second concern is that regardless of future policies banning trade in e-scrap, trade bans will not solve the challenge of informal recycling because additional obsolete electronics will be generated domestically in the developing world. Yu and collaborators showed that by 2016-2018 the developing world is expected to generate more end-of-life computers than the developed world [14].

The third concern for bans as a policy tool to address informal recycling is negative trade-offs on economic and social issues. Table 1 summarizes positive and negative outcomes. Successful trade bans and outlawing informal recycling would reduce environmental impacts of informal recycling and increase employment in the formal sector, taking up the slack of reduced informal activity. However, there would also be negative consequences of reduced reuse and access to used equipment, and informal sector employment. Demand for used electronics is higher in the developing world than the developed; a significant part of the e-scrap trade is machines destined for reuse [15]. Robust used markets both provide employment and access to equipment to lower income groups. Due to the challenge of distinguishing useful from useless devices, well-intentioned policies aimed at eliminating trade in waste electronics hamper international flows of items intended for reuse [16]. While outlawing informal recycling does not necessarily lead to reduced reuse, in practice formal recycling systems, implemented to take over from the informal sector, emphasize materials recycling over reuse [16,17]. While changes in employment in formal and informal sectors is difficult to estimate numerically, it is important to note that informal reuse and recycling workers are particularly vulnerable.

Table 1. Environmental, social and economic trade-offs for different policy interventions to address informal recycling.

\begin{tabular}{cccc}
\hline & Trade Bans & Outlaw informal recycling & Economic intervention \\
\hline Reuse/access to equipment & $\downarrow$ & $\downarrow$ & - \\
Mitigate recycling impacts & $\uparrow$ & $\uparrow$ & $\uparrow$ \\
Jobs in formal sector & $\uparrow$ & $\uparrow$ & $\uparrow$ \\
Jobs in informal sector & $\downarrow$ & $\downarrow$ & - \\
\hline
\end{tabular}

Considering the feasibility of implementation and the negative social and economic consequences of trade bans and outlawing informal recycling, we argue it is important to explore policy alternatives that manage environmental impacts while preserving social and economic benefits $[15,18]$.

The informal sector is extremely effective at collection, repair, reselling and dismantling electronics. One can argue it is beneficial to leave these activities in the hands of the free market, intervening only where environmental problems arise: informal practices such as chemical recovery of gold from circuit boards, burning wire insulation and dumping residual waste. The idea is thus to link informal and formal sectors, as illustrated in Figure 1. The mechanism proposed to achieve diversion is provision of a financial incentive to informal recyclers in order to turn over certain parts for formal processing [16,19]. This article explores the organizational issues associated with providing such an economic incentive. 
Figure 1. Example of linking informal and formal sectors via an economic instrument.

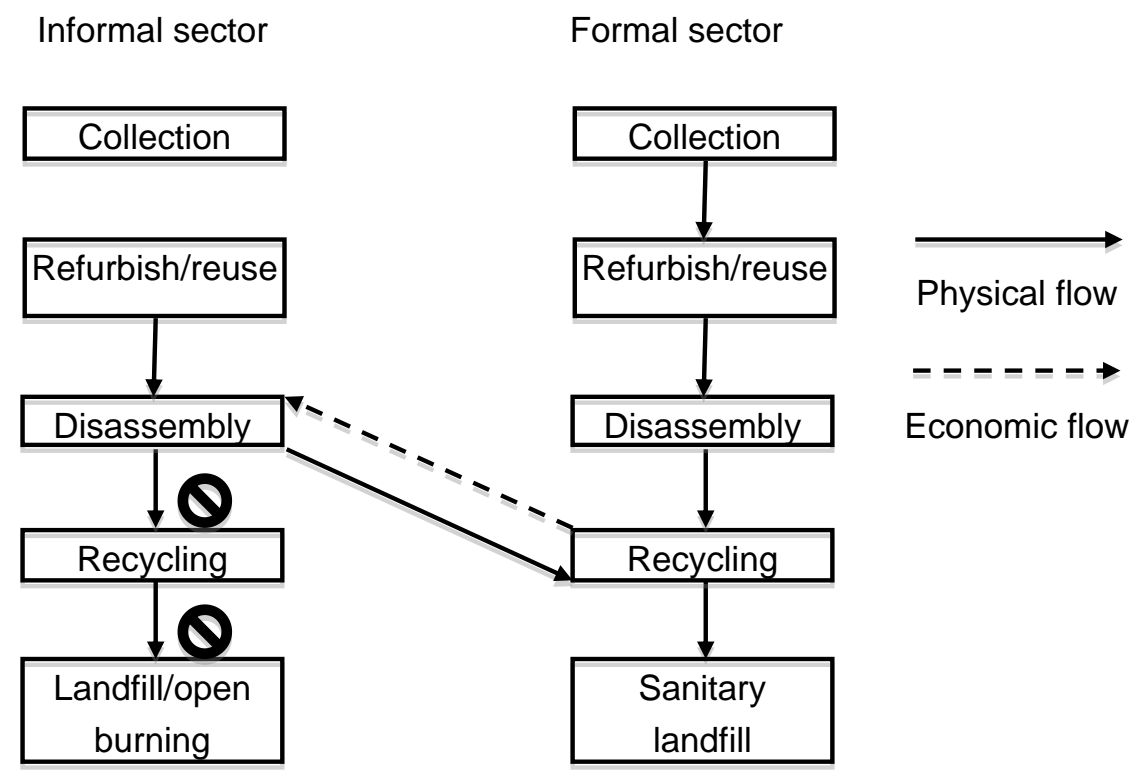

Section 2 introduces the interface organization. Section 3 frames the environmental objectives of an interface organization. Economics is discussed in Section 4, starting with development of a model to determine if the organization is market or subsidy based, followed by discussion of policy issues in private and publicly subsidized cases. Section 5 treats social issues, in particular the possible failure modes of an interface organization due to institutional and social constraints. Section 6 delves into informal versus formal recycling of printed circuit boards.

\section{Linking Informal and Formal Sectors: The Interface Organization}

In the previous section, we argued for provision of targeted economic incentive to redirect certain parts and materials from the informal sector for processing in the formal sector. To review the state of work on linking informal and formal sectors, one of us (Williams) proposed the creation of collection points that pay informal recyclers a marginal dividend to turn over printed circuit boards, copper wires and residual waste for formal processing and landfills [15,19]. Keller [20] and Rochat and collaborators [21] analyze and compare the efficiency of informal hydrometallurgical processes for recovering gold from scrap circuit boards with integrated metals refineries. Their crucial result is modern integrated smelters recover far more gold than informal recycling as practiced in India (>95\% yield for formal vs. 25\% yield for informal). This difference in yields implies that formal recycling of circuit boards is economically preferable to informal recycling. This suggests that informal recycling of circuit boards is a market failure. Yu and colleagues analyze e-scrap policy constraints in China and suggest informal-formal linkages as a solution to insufficient collection under current Chinese policies [22]. The Solve the e-Waste Problem (StEP) Initiative of the United Nations University terms mixing informal and formal processing as "Best of 2 Worlds" [23,24]. Manhart performs a scenario analysis comparing pure informal, formal, and mixed systems and finds that sustainability benefits are possible in the mixed systems [23]. Wang and colleagues similarly find resource recovery, economic and environmental benefits of mixed informal-formal systems, and relate experiences with pilot 
projects in China and India [24]. A 2013 StEP report on electronics recycling in China calls "for exploration of solution oriented research (such as environmental and affordable technologies, economic measures, effective managing policy etc.) will fundamentally help to transfer or upgrade the pollution activities of informal recycling" [25].

The above literature establishes the potential benefits of mixing informal and formal sectors. The critical open question is how to achieve the mixture in a practical way that meets desired environmental, economic, and social goals. While we cannot hope to answer this question in a single article, in this article we aim to contribute to the following aspects:

- Introduce the interface organization that links informal and formal sectors as an object of formal analysis;

- Build an assessment framework to support future designs of interface organizations;

- Examine informal and formal recycling of circuit boards to extract general lessons for interface organizations.

The concept of an interface organization is summarized in Figure 2. The interface organization buys parts, materials, and/or scrap devices from informal collectors and dismantlers and sells them to formal recycling firms. The interface organization is a registered institution and is compliant with regional and global environmental and trade regulations. The private versus public nature of the organization depends on the economics of its targeted mission. We identify four types of material flows from informal dismantlers. Type I flows are materials and parts that can be directly used in the formal sector, such as used Dynamic Random Access Memory (DRAM) and Central Processing Units (CPUs) or pure material streams such as aluminum or steel parts. We argue these material streams need no policy intervention, as informal dismantlers sell to the formal sector for direct reuse. Type II materials/parts are more profitable to process formally, i.e., recall that authors of [20,21] argue that this is the case for circuit boards. Here, the role of the interface organization is to bridge market failures (discussed later) and channel scrap circuit boards from informal dismantlers to integrated metal refineries. Type III materials/parts have value in the formal recycling sector, but the cost to recycle is lower in the informal sector. Copper wires with insulation looks to be a major type III flow. Redirection to formal processing requires a financial instrument to incentivize the informal to formal flow. Type IV flows are types of "residual waste", such as some plastic cases and various plastic pieces. While recycling is possible in principle, there are some parts and residuals without sufficient value to recycle without significant public subsidy. The "best" (this is clearly subjective) destination for type IV flows is a well-managed sanitary landfill. As with type III flows, some form of incentive/facilitation is needed to channel residual waste to landfills. However, the fate of type IV flows can change in the near future as new uses are discovered for these materials.

To our knowledge, there is as yet no analysis of organizational issues associated with linking informal to formal recycling. We thus devote this work to a largely conceptual discussion of the objectives, structure and challenges facing an interface organization. 
Figure 2. The interface organization as an intermediary between informal and formal sector.

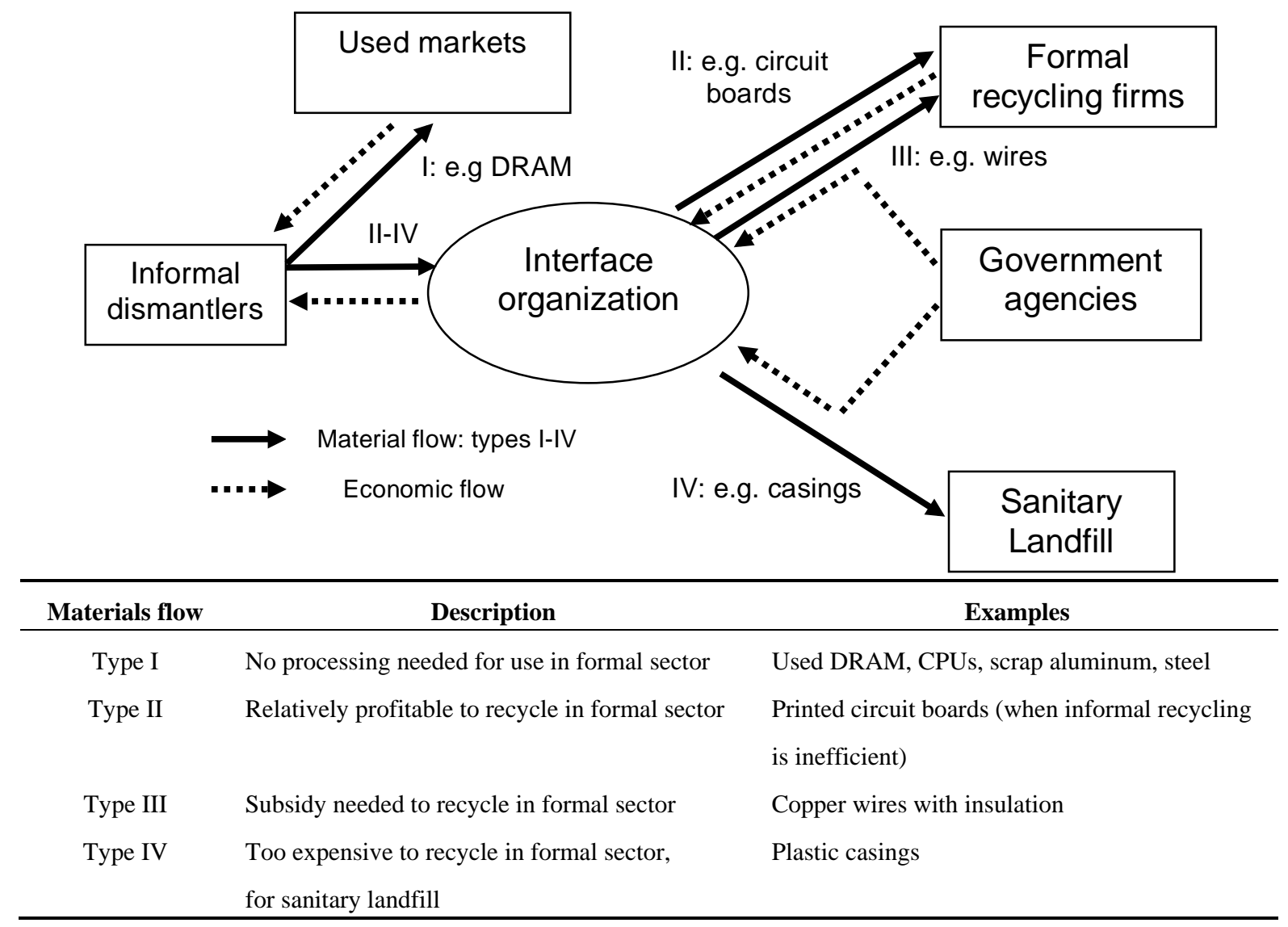

\section{Environmental Issues}

The rationale to mitigate environmental impacts by linking formal and informal sectors is based on the premise that some informal processes do not pose significant risk. Thus, intervention is only needed for those processes deemed unacceptable. How to decide which processes require intervention? Overall, informal recycling poses environmental hazards and scientific evidence showing that its pollution is serious is mounting. See $[7,16,26]$ for reviews of health issues. It remains poorly understood, however, specifically what informal processes cause what impacts. Some practices such as cyanide/acid treatment of circuit boards and open burning of wire insulation are clearly high impact and should be avoided. Others processes such as informal collection, repair, and possibly, dismantling of equipment may not be significantly riskier than their formal counterparts. Table 2 shows a list of known and potential processes of concern. More research is needed to clarify environmental impacts. Note that to achieve the function of preventing undesired recycling, the interface organization must ensure it purchases parts before the process takes place, e.g., it does not purchase already treated circuit boards or burnt wires. The approach taken here is not to preempt the results of this future research and is instead to develop a general framework for designing interface organizations based on future decisions as to what flows need to be channeled to the formal sector. 
Table 2. Partial list of environmental concerns in informal recycling of electronics $(\mathrm{CRT}=$ Cathode Ray Tube).

\begin{tabular}{|c|c|c|}
\hline Objective & Informal process & Environmental concerns \\
\hline Chip removal & $\begin{array}{l}\text { Heating/baking of circuit boards } \\
\text { with manual chip pulling }\end{array}$ & $\begin{array}{l}\text { Lead and other emissions from heating } \\
\text { boards }\end{array}$ \\
\hline $\begin{array}{l}\text { Gold and copper recovery } \\
\text { from circuit boards }\end{array}$ & $\begin{array}{l}\text { Hydrometallurgical processing } \\
\text { using cyanide and acids }\end{array}$ & Chemical and leached metal emissions \\
\hline Copper recovery from wires & Open burning of wire insulation & $\begin{array}{l}\text { Generation of dioxins, furans and other } \\
\text { pollutants }\end{array}$ \\
\hline Dispose of residual waste & Accumulation in open fills & $\begin{array}{l}\text { Leaching of metals and brominated } \\
\text { flame retardents; dioxins and furans } \\
\text { caused by dump fires }\end{array}$ \\
\hline CRT recovery & Manual separation of tubes & Lead exposure \\
\hline
\end{tabular}

\section{Economics: Market versus Subsidy Economic Model}

Economic instruments are a promising approach to achieve the appropriate flows between informal and formal sectors. An economic instrument is defined as a socially-mandated increase or decrease in the price of a good in order to shift business or consumer behavior [27,28]. In 2005, one of us proposed use of an economic instrument to link informal and formal electronics recycling [19]. The premise is to introduce a financial incentive to tip the economic scales such that informal collectors, dismantlers and recyclers get a higher price to turn in components to be processed in the formal sector rather than recycle themselves. Such an economic intervention could be made in different parts of the reverse supply chain from used machines to individual components.

In fact, in some cases a formal financial incentive might not be necessary to connect informal and formal sectors: Informal actors could already get a higher price by selling to the formal recyclers; they just need the opportunity to participate in a competitive market. For example, while informal recycling of circuit boards is reported in China and India, in Peru and Mexico, instead of recycling themselves, informal dismantlers sell circuit boards to intermediaries for export, for formal recycling abroad [15,29]. As mentioned earlier, Rochat and collaborators show a higher profit for Indian informal recyclers to export circuit boards for recycling in Europe rather than process themselves [21].

Depending on the process, differences in economic and technology conditions can shift the profitability of informal versus formal recycling. Which is more profitable is a key question for policy interventions. If informal recycling is more profitable than formal recycling, public subsidy is needed to channel the flow from informal to formal processing. If formal recycling is more profitable than informal, formal recycling will win when markets are functional. In this section, a model is developed to determine when a flow from informal to formal sector needs to be subsidized versus follow market forces. In section 4.2, the subsidy case is explored, while section 4.3 discusses the case when formal recycling is more profitable but hindered by dysfunctional markets. 


\subsection{Modeling Profitability of Informal to Formal Flow}

To clarify economic relationships, we build an economic model that compares the profitability of informal recycling versus transport from an informal site followed by formal processing. The profit of recycling a mass of product $M$ is

$$
\text { Profit of recycling }=\text { Revenue }- \text { Cost }=\text { M Y P }- \text { M U }
$$

where $\mathrm{Y}$ is the yield of recovering materials, $\mathrm{P}$ is the average price of recovered materials, and $\mathrm{U}$ is the average cost of processing and other related costs.

Denoting the characteristics of formal and informal recycling processes with subscripts $\mathrm{f}$ and $\mathrm{i}$, respectively, and assuming material market prices are the same in both cases, the profitability of foregoing informal recycling and shipping to formal recycling is

$$
\text { Profit to transfer }=M Y_{f} P-M U_{f}-\left(M Y_{i} P_{i}-M U_{i}\right)-M T_{i f}
$$

Or

$$
\text { Profit to transfer/M }=P\left(Y_{f}-Y_{i}\right)-\left(U_{f}-U_{i}\right)-T_{i f}
$$

where $T_{\text {if }}$ is the unit cost to transport materials from the informal to a formal facility.

Calculating the above equation depends on data not generally available. Rochat and collaborators examined the situation for circuit board recycling in India and found profitable the transfer to European integrated smelters [21]. We use their data to model how varying material prices and technological conditions in informal recycling will affect the profitability of transfer. Let $\mathrm{T}_{\text {if }}$ and $\left(U_{f}-U_{i}\right)$ be constant. The line of zero profit in the $\mathrm{P}-\left(\mathrm{Y}_{\mathrm{f}}-\mathrm{Y}_{\mathrm{i}}\right)$ space is given by

$$
\mathrm{P}=\left(\mathrm{T}_{\mathrm{if}}+\mathrm{U}_{\mathrm{f}}-\mathrm{U}_{\mathrm{i}}\right) /\left(\mathrm{Y}_{\mathrm{f}}-\mathrm{Y}_{\mathrm{i}}\right)
$$

According to (Rochat et al. 2007), $T_{\text {if }}=600$ euros/ton and $U_{\mathrm{f}}-U_{i}=200$ euros/ton. Figure 3 shows the profitability $=0$ curve in the materials value-yield space.

According to this model, the 2007 results from Rochat and collaborators are robust under a wide range of price and technology changes. With the same technology, metal prices would have to fall to $25 \%$ of 2007 values to lose profitability. Keeping prices at the 2007 level, informal recycling has to attain yields greater than $80 \%$ to be profitable. Low yield is not intrinsic to hydrometallurgical processing, laboratory studies of leaching with aqua regia report yields of 93\%-98\% for gold, silver and palladium [30]. Little is known, however, as to what yields are feasible for informal recycling. There are also anecdotal reports of informal recyclers selling their liquid residual for further processing by formal firms.

This example illustrates the general utility of the model. Clearly different components and aggregations of components results could yield very different results. For example, while there are concrete examples where circuit boards are indeed exported from informal to formal recyclers based on profitability [15,29], scrap wires are apparently not exported. This means that local infrastructure is capable of recycling wires and that exportation would not be profitable. 
Figure 3. Profitability of transferring circuit boards from informal recyclers in India to formal recyclers in Europe as function of price and technology difference. The shaded area represents the unprofitable region.

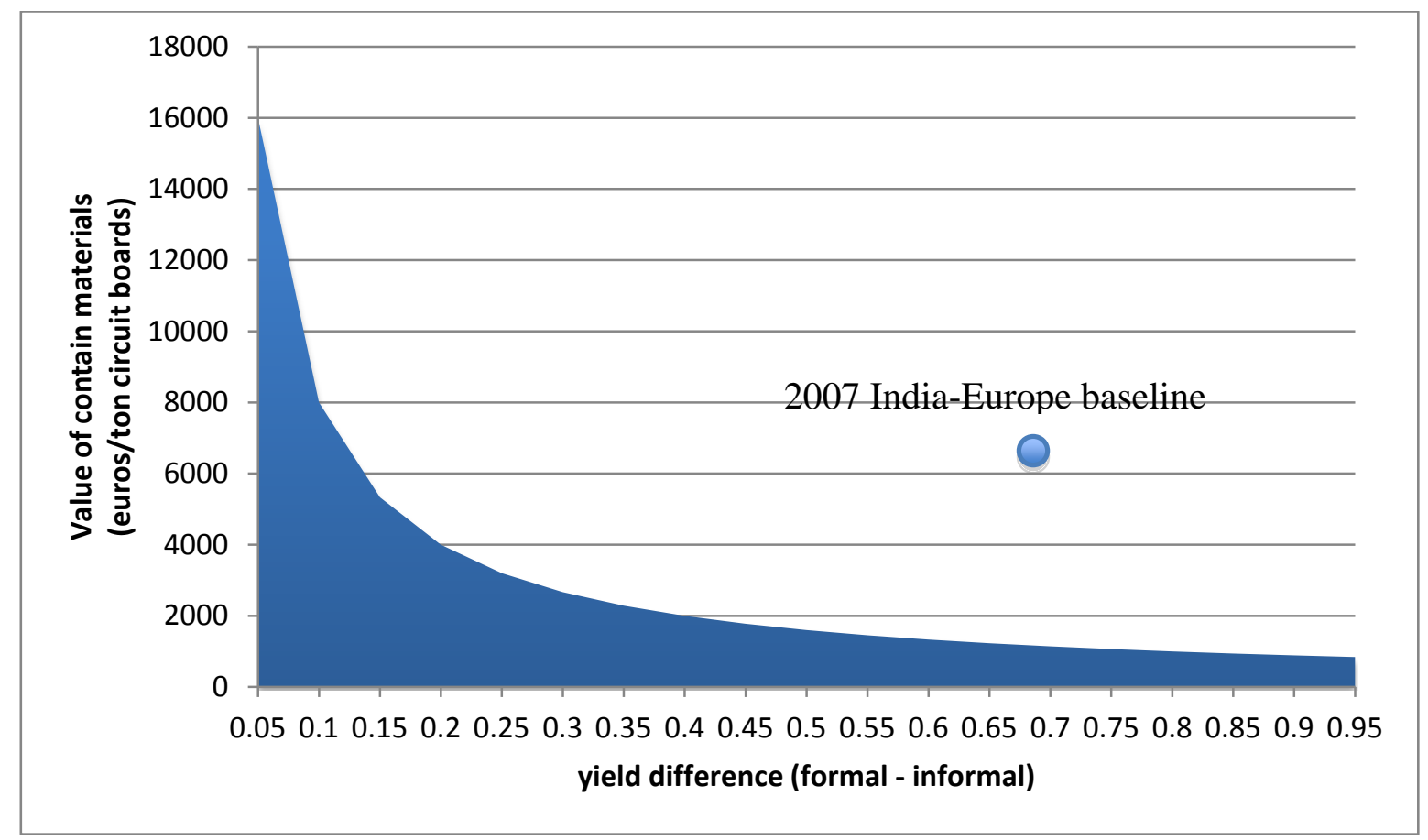

\subsection{Unprofitable Transfer from Informal to Formal: Subsidy Instrument}

In the case when informal recycling is more profitable than formal recycling, market forces alone will not lead to interface organizations. In this case, the interface organization is a subsidized quasipublic entity designed to deliver a public good (avoided informal recycling and related negative impacts to the environment and public health). The subsidy needed is just enough to tip the balance in Equation (3) to ensure that informal collectors and dismantlers are paid more to sell to the interface organization rather than to informal recyclers or by recycling it themself.

The interface organization could be implemented via different organizational models. One model sets the interface organization not as a market driven, but subsidized entity. A price subsidy that pushes the collection of the material and parts to net profitability is set by some public organization. The interface organization then bills public funds collected for electronics end-of-life mechanisms, such as the e-market for returned deposit or Extended Producer Responsibility, according to the volume of material process and this price. Appropriate mechanisms need to be established for the international transfer of recycling funds. See Kahhat et al. for discussion on an international financing mechanism [17].

Alternatively, the function of an interface organization could be assumed by a governmental agency, such as a local municipal waste management organization. The financing structure could be the same as the private case or follow other models, such as public funds covering operating expenses of the organization.

The question of how to finance the subsidy to the interface organization is critical. One portion of the waste stream handled by interface organizations is domestically generated. Processing domestic 
e-scrap would presumably be handled via domestic funds gathered locally or nationally as part of a waste management system. In many areas, funds for electronics recycling are separately collected through recycling fees paid by consumers or extended producer responsibility systems. E-scrap processed by the interface organization that comes from abroad raises the possibility of establishing an international system of payments to ensure proper recycling.

\subsection{Profitability for Informal to Formal Transfer: Dysfunctional Markets}

The economic profitability of transfers from the informal to formal sector does not necessarily ensure that they occur. There can be market failures due to social or organizational barriers. Market failure refers to the general phenomenon of non-optimal allocation of economic resources due to social or institutional barriers and transaction costs [31]. Market failures are often associated with information asymmetries, non-competitive markets, externalities, or public goods. Much of the literature on market failures focus on issues different from those at play in informal recycling, so we use the word dysfunctional market to refer to institutional or social factors leading to a lack of transfer from the informal to formal sector, even when such a transfer would be financially profitable.

The causes and potential solutions to dysfunctional markets need further research. To inform this agenda we suggest four possible obstacles. Here, we categorize and describe obstacles to interface organizations that could lead to market failures. One factor could be the problematic legal status of informal recycling. While an interface organization does not engage in either informal collection and dismantling or importation of e-scrap, if either or both of these activities are illegal in a jurisdiction the legal position of an interface organization could be at risk. A second factor could be insufficient knowledge on the part of informal collectors and dismantlers, and integrated smelters of the opportunity to create a business link. A third factor is lack of capital to establish an interface organization. While an interface organization is not capital intensive, there is a need to establish appropriate collection facilities as well as a system for purchasing, selling and exporting circuit boards. Time delays between purchasing boards from informal dismantlers and receiving payments from integrated refineries imply that a substantial financial buffer is needed. A fourth type of failure could be reluctance on the part of integrated refineries to enter into a business relationship connected with the informal sector. Informal collection and dismantling is associated with informal recycling, the latter has a decidedly negative public image. Finally, a fifth reason behind a dysfunctional market could be if there are strong loyalties within the informal recycling chain or if informal recyclers have non-economic means, such as threats of violence, for persuading collectors and dismantlers to sell to them rather than to an interface organization.

When market failures prevent emergence of an interface organization, environmental policy could take the form of interventions to resolve market failures. This is a qualitatively different role compared to traditional command and control policy or economic instruments. 


\section{Social Issues}

Given that social and institutional constraints led to failure of command and control policies to address informal recycling, it is important to consider potential failures of the interface organization model. Here we identify and attempt to address failure modes. Real-world design of an interface organization system would need to carefully plan the avoidance of these and other potential pitfalls.

One potential failure is lack of participation by informal recyclers. While the system is designed to provide an economic incentive to the informal sector, this does not guarantee participation. Given the hostility that the informal sector has faced in the past, establishment of trust could be challenging. Explicit efforts to build trust in the system might be necessary. It is therefore important that the system be designed in consultation with the informal sector and with consideration of its needs. For example, informal processing is often based on cash based payment at the point of sale. There can also be a need for training/reskilling of recyclers and efforts to generate alternative forms of employment. Note that when the informal end-of-life sector has specialized to the degree where separate groups handle collection, dismantling, sorting and recycling processes, not all workers benefit from the interface organization: those engaged in recycling will be displaced by redirection to the formal sector.

A second failure mode is corruption. When public funds are collected to subsidize the system, there is the potential for fraud, i.e., charges billed for parts and equipment not actually sent for formal recycling. Real-time verification systems are needed. One possibility is to route the subsidy through the formal recycling firms receiving the equipment. In other words, the formal recycling firm pays a premium price to certified interface organizations. Corruption is presumably reduced since medium and larger firms are easier to monitor than local governments and face a larger risk if abuses are exposed.

A third potential problem is smuggling. As mentioned in section 4.2, there are different institutional arrangements that could finance a subsidy system to encourage flows from informal to formal recycling. There is the potential for "free riders", i.e., equipment processed from areas that are not contributing to the subsidy. For example, if the subsidy is provided from a national government, imported equipment becomes a free rider. Traceability systems could solve this problem: information tags in electronics would verify that components processed by an interface organization, e.g., as described in [17]. Such an information tag system is, however, years away from realization.

\section{Case Study of Circuit Board Recycling}

The discussion thus far has been generic, applying to any component or material in electronics. It is worth considering a specific component in more detail. We analyze circuit boards in this section, including data on materials content and value, information on informal versus formal recycling efficiencies, and organizational/institutional issues.

\subsection{Metals Content of Circuit Boards}

The economic driver of circuit board recycling is their content of precious metal and basic metals, with gold, silver, palladium, and copper being the most important ones. The content of different metals, including hazardous metals, varies substantially depending on the type of circuit boards, as shown in Table 3. 
Table 3. Content by weight of precious and other metals in different types of circuit boards $($ Unit $=\%)(\mathrm{PC}=$ personal computer, $\mathrm{MD}=$ mini-disc, $\mathrm{CD}=$ compact disc, $\mathrm{LCD}=$ liquid crystal display, $\mathrm{HD}=$ hard disc).

\begin{tabular}{cccccccc}
\hline & $\mathbf{A u}$ & $\mathbf{A g}$ & $\mathbf{P d}$ & $\mathbf{C u}$ & $\mathbf{P b}$ & $\mathbf{B i}$ & $\mathbf{S n}$ \\
\hline PC (desktop) motherboard & 0.012 & 0.062 & 0.016 & 13.7 & 1.57 & N.A. & 2.48 \\
PC (desktop) network card & 0.014 & 0.067 & 0.014 & 18.8 & 0.97 & N.A. & 1.38 \\
Video camera & 0.07 & 0.39 & 0.15 & 22.5 & 3.1 & 0.18 & 3.8 \\
Stereo system & 0.03 & 0.26 & $<0.01$ & 17.2 & 0.16 & $<0.01$ & 2.8 \\
Digital camera & 0.03 & 0.32 & 0.01 & 29.2 & 1.6 & 0.03 & 3.0 \\
Portable MD player & 0.09 & 0.34 & $<0.01$ & 30.7 & 0.35 & $<0.01$ & 5.3 \\
Portable CD player & 0.05 & 0.37 & $<0.01$ & 20.8 & 0.12 & 0.01 & 6.4 \\
LCD TV & 0.02 & 0.06 & $<0.01$ & 17.7 & 1.7 & $<0.01$ & 2.9 \\
DVD player & 0.02 & 0.16 & $<0.01$ & 19.0 & 1.2 & $<0.01$ & 2.1 \\
Phone & $<0.01$ & 0.24 & $<0.01$ & 9.6 & 1.9 & 0.04 & 3.4 \\
Car navigation & 0.01 & 0.19 & $<0.01$ & 33.0 & 0.04 & $<0.01$ & 2.7 \\
Game machine & 0.02 & 0.08 & $<0.01$ & 19.2 & 1.6 & 0.03 & 2.9 \\
Plasma TV & 0.03 & 0.04 & $<0.01$ & 21.8 & 1.1 & 0.01 & 2.1 \\
Flash memory music player & 0.09 & 0.26 & $<0.01$ & 18.5 & 0.03 & $<0.01$ & 2.0 \\
HD music player & 0.07 & 0.28 & $<0.01$ & 52.9 & 0.02 & $<0.01$ & 5.3 \\
Cell phone & 0.16 & 0.51 & 0.02 & 34.6 & 1.3 & $<0.01$ & 3.7 \\
\hline Sour & &
\end{tabular}

Sources: [32] for all except personal computer (PC), [33] for personal computer.

The value of the metals contained in different types of circuit boards is shown in Figure 4. This figure is based on Table 3, with the value of each circuit board per ton calculated applying the following 2011 market prices: 59,000USD/kg for gold; 1,160USD/kg for silver; 24,000USD/kg for Palladium; 8USD/kg for Copper; 8USD/kg for Lead; 20USD/kg for Bismuth; and 23USD/kg for Tin ([34] for gold, silver, palladium, average 2011 March prices); [35] for Copper, Lead, and Tin, average of March, 2011 prices; [36] for Bismuth, the price based on December, 2008). These figures only reflect the value of contained metal without considering recycling costs, recovery rates, or other relevant costs. Gold dominates total value, ranging between $51 \%$ and $91 \%$, depending on the type of circuit board. Copper and silver tend to be the next most valuable, with palladium being significant for video camera, cell phone, and PC boards. 
Figure 4. Economic value of metals contained in different types of circuit boards.

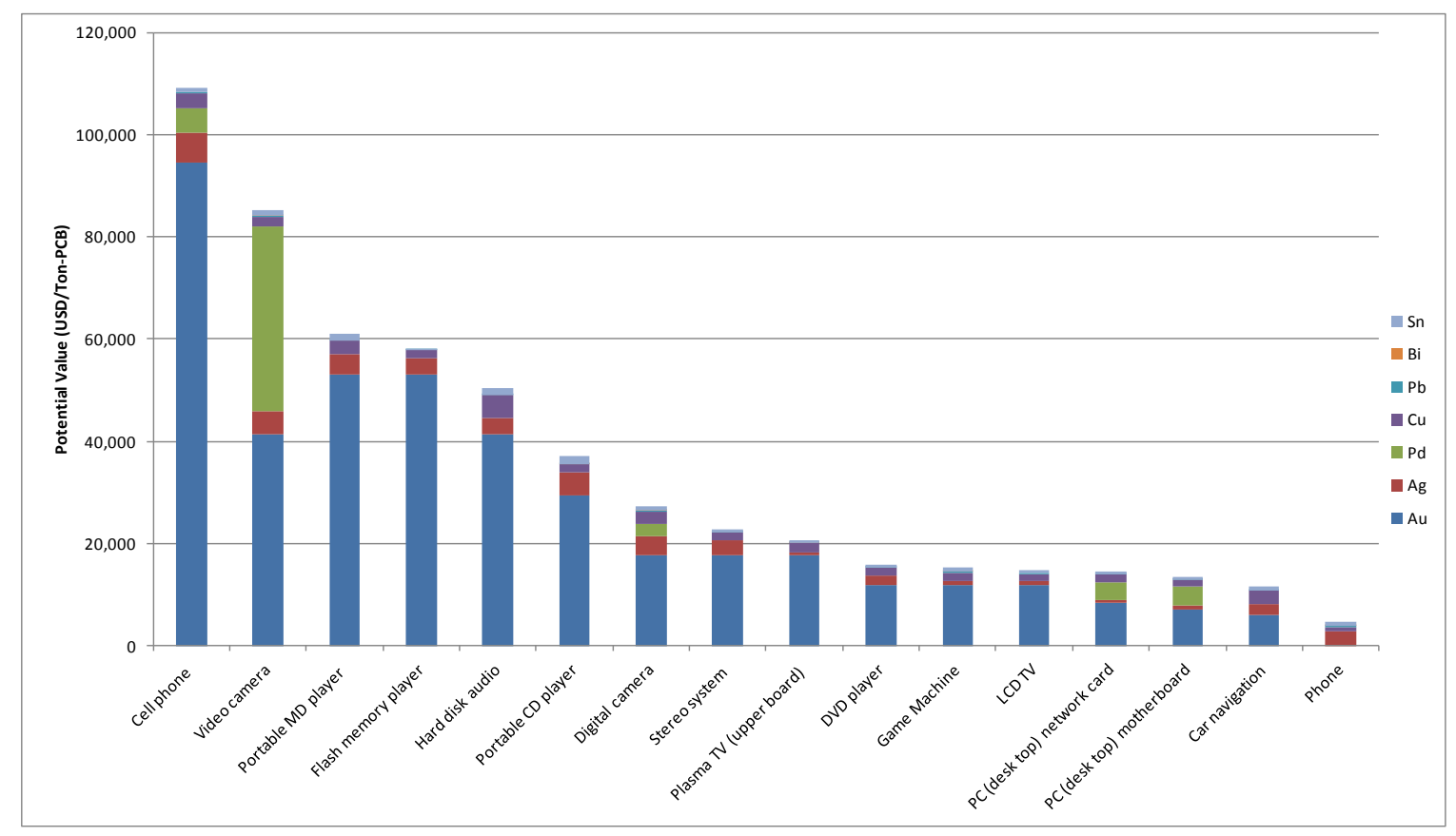

\subsection{Comparison of Economic and Environmental Performance of Formal and Informal} Recycling Processes

Formal and informal recyclers employ different methods for recovering metals from printed circuit boards. More information about the technological aspects of circuit board recycling processes can be found in [30]. To recap informal recycling, the main publicly available data point is that only $25 \%$ of total gold contained in boards is recovered by the cyanide wet chemical processes practiced by informal recyclers in India. 58\% of total gold will remain in the circuit board and 5\% of total gold will be emitted as dust during the separation of connectors and boards [20,21]. Bare circuit boards can be sent for further processing to recover copper. During the gold extraction process from connectors, a significant fraction of the gold is lost as scrap metals (5.5\% of total gold) and gas/liquid (6\% of total gold). One area for future research is to clarify the technical processes and actual efficiencies of informal recycling. An anecdotal source [37] suggests that yields for Chinese informal recycling of circuit boards may be much higher than the Indian case according to [20,21].

In comparison, integrated metals refineries can recover many types of metals at high rates. For example, the Umicore facility in Belgium can recover 17 different metals, with recovery rates for Ag, $\mathrm{Au}, \mathrm{Pd}, \mathrm{Pt}, \mathrm{Cu}, \mathrm{Pb}$, and $\mathrm{B}$ greater than $95 \%$ [38]. The dramatic difference in recovery rates for many metals between formal and informal recycling have led some researchers to suggest that informal recycling should be avoided due to materials scarcity [39].

There is an open question regarding at what point circuit boards should enter the interface organization, whether before or after pulling of valuable microchips. Informal pulling of microchips from boards could pose an environmental risk since boards are typically heated over open stoves to melt solder. Lead in this solder could become airborne or contaminate processing sites. Further work is needed to clarify this risk, and depending on the results, the interface organization is set to either accept populated or depopulated boards. 


\subsection{Client-Firm Business Model for Integrated Metals Refineries}

This section reviews current practice in the business relationship between electronics dismantlers and integrated metals refineries handling circuit boards. In order to ensure a stable supply, integrated metals refineries stipulate a variety of terms. The contract length between integrated metals refiners and clients (suppliers of boards) is typically 1-2 years. This contract stipulates a minimum volume of circuit boards and lot size that clients will supply as a few hundred tons of boards in 5-10 tons lots. There are typically two types of contract: one is that client pays the refiner for the recycling service and then takes the metals back for their own use and the other is that the refiner give the net payments to the client and keeps the metals recovered.

The content of precious metals in circuit boards, as shown in Table 3, varies substantially depending on device types, generations, and models. There is thus a need for measurement of metal content of boards, an evaluation processes usually carried out by refineries. After the boards arrive at the refinery, the boards are visually inspected and then shredded with an automated process to homogenize material for sampling process. For more detailed measurement, a sub-sample is taken and melted into an ingot that undergoes assessment of precious metal content. This content determines the price paid for the circuit board. The sampling process usually takes three months (Rochat, 2007). Clients are typically allowed to observe (when a representative can be sent) the process and sometimes the client will send out samples for their own testing. The technical challenge of accurate valuation of metals in circuit boards creates an information asymmetry between buyer and seller.

\subsection{Example of Functioning Interface Organization: Peru Recicla}

When conditions are favorable, properly functioning markets should ensure that Adam Smith's invisible hand leads to the natural emergence of interface organizations. In Peru, the company Peru Recicla, reflects just such a case. Peru Recicla, a division of Compañia Química Industrial de Pacifico S.A., is one of the few companies in Peru that offers full service e-scrap management solutions, including data destruction, equipment destruction, assets management, and recycling certificates. After electronic dismantling and destruction, certain materials, such as base metals are sold to the local market and others landfilled in well-managed industrial landfills.

Peru Recicla firm obtains scrap circuit boards from these e-scrap services provided to local businesses. The supply of scrap circuit boards from local businesses is not sufficient; however, to comply with its contractual agreement with the Hamburg-based smelter Aurubis (formerly Norddeutsche Affinerie AG), Peru Recicla thus also buys scrap circuit board from the informal collection and dismantling market in Lima. According to Domingo Salaverry, owner of Peru Recicla, $50 \%$ of the circuit boards in a container shipped to Germany typically comes from the informal sector [40]. Peru Recicla exported around 50 tons of shredded scrap circuit boards to Hamburg in 2008 and 21 tons the first quarter of 2009 [41]. It is important to note that scrap circuit boards are also exported to China by a different Peruvian company [15]. 


\subsection{Lessons Learned From Circuit Board Case}

The analysis of circuit boards raises general issues for the design of interface organizations. One issue is the need for systems to assign prices to products of different grades. The wide range in materials value for different types of circuit boards applies to other components as well. The interface organization will need practical systems that divide components into workable categories that also reflect their value. In the case of circuit boards, the recycling industry is already to some extent using a simple grading system (grades A, B and C) based on gold contents. Similar systems are likely to exist for components like cables, but on an informal basis. Maintaining a strong business aspect to the organization can presumably aid to ensure efficient systems are developed and implemented.

A second issue raised is that the business model for formal recyclers varies by component. The need for scale and guaranteed volumes to work with integrated metal refineries is notable. Informal recyclers cannot directly work with such firms, a key role for the interface organization in this case to act as guarantor. Business models for destination components in the formal sector need to be built into the design of the interface organization.

A third issue is how to leverage existing institutions in building interface organizations. In Peru and Mexico, market forces have led to a formal recycling firm taking on the role of an interface organization. The expertise within the firm for its internal recycling no doubt plays an important role in being an effective collector of equipment from the informal sector. It is premature to assert that formal recyclers should also be interface organizations; the point is that design of the system should examine existing institutions and build in interface capacity, accordingly.

\section{Discussion and Future Work}

This article has presented a framework for developing interface organizations as a policy option. Much work remains to test the concept and work towards practical implementation, and we have commented on particular needs in individual sections. In taking a a broader perspective, note that for the sake of simplicity, we laid out an assessment framework at a component/material level. The interface organization system would handle a number of components. While the organization could run a profit on some components, such as circuit boards, to realize its social purpose the interface organization needs to channel all targeted streams to appropriate processes, many of which will not be profitable (e.g., transporting final waste to sanitary landfill). The design process thus also integrates treatment of individual components to realize an overall system. While many questions remain, we hope that this work contributes to the development of effective policies to mitigate the environmental impacts of informal recycling while maintaining employment and access to equipment for peoples in the developing world.

\section{Acknowledgements}

This research was supported by the "Tekisei-na kokusai-shigen-jyunkan wo mezasita seihin-chu no yuuyou busitsu oyobi yuugai busitsu no kanri no arikata ni kansuru kenkyu (Research on management of valuables and hazardous materials in products aiming for environmentally sound international resource circulation) (K2166)", which has been funded under the waste management research grant 
from Ministry of Environment, Japan and by the U.S. National Science Foundation, via Grant CBET-0731067 in the Environmental Sustainability program. The authors would like to thank Christian Hageluken, Masayuki Naka, Michikazu Kojima, Amit Jain and Domingo Salaverry for their invaluable input to this work.

\section{References}

1. Basel Action Network; Silicon Valley Toxics Coalition. Exporting Harm: The High-tech Trashing of Asia; Available online: http://www.ban.org/E-waste/technotrashfinalcomp.pdf (accessed on 1 August 2009).

2. Toxics Link. Scrapping the High-tech Myth, Computer Waste in India; Toxics Link: Delhi, India, 2003.

3. Basel Action Network. The Digital Dump: Exporting Re-use and Abuse to Africa; Basel Action Network: Seattle, WA, USA, 2005.

4. Deng, W.; Louie, P.; Liu, W.; Bi, X.; Fu, J.; Wong, M. Atmospheric levels and cytotoxicity of PAHs and heavy metals in TSP and $\mathrm{PM}_{2.5}$ at an electronic waste recycling site in southeast China. Atmos. Environ. 2006, 40, 6945-6955.

5. Leung, A.; Cai, Z.W.; Wong, M.H. Environmental contamination from electronic waste recycling at Guiyu, southeast China. J. Mater. Cycles Waste Manag. 2006, 8, 21-33.

6. Huo, X.; Peng, L.; Xu, X.; Zheng, L.; Qiu, B.; Qi, Z.; Zhang, B.; Han, D.; Piao, Z. Elevated blood lead levels of children in Guiyu, an electronic waste recycling town in China. Environ. Health Perspect. 2007, 115, 1113-1117.

7. Tsydenova, O.; Bengtsson, M. Chemical hazards associated with treatment of waste electrical and electronic equipment. Waste Manage. 2011, 31, 45-58.

8. Notification on Importation of the Seventh Category Waste; Ministry of Environmental Protection: Beijing, China, 2000.

9. Basel Convention on the Control of Transboundary Movements of Hazardous Wastes and their Disposal, 1989. Available online: http://www.basel.int/text/documents.html (accessed on 1 August 2009).

10. The Circular on Strengthening Environmental Management of Waste Electrical and Electronic Equipment; Ministry of Environmental Protection: Beijing, China, 2003.

11. Chisholm, M.; Bu, K. China's E-waste Capital Chokes on Old Computers. In Reuters News Service; Reuters: New York, NY, 2007. Available online: http://www.reuters.com/article/ 2007/06/11/idUSPEK148230 (accessed on 17 July 2013).

12. Warren, P. Organised Crime Targets Waste Recycling. The Guardian, 8 July 2009; Available online: http://www.guardian.co.uk/technology/2009/jul/08/recycling-electronic-waste-crime (accessed on 17 July 2013).

13. Lewis, A. Europe Shipping Electronic Waste. BBC News Europe, 4 August 2010; Available online: http://www.bbc.co.uk/news/world-europe-10846395 (accessed on 4 August 2010).

14. Kahhat, R.; Williams, E. Product or waste? Importation and end-of-life processing of computers in Peru. Environ. Sci. Technol. 2009, 43, 6010-6016. 
15. Yu, J.L.; Williams, E.; Ju, M.T.; Yang, Y. Forecasting global generation of obsolete personal computers. Environ. Sci. Technol. 2010, 44, 3232-3237.

16. Williams, E.; Kahhat, R.; Allenby, B.; Kavazanjian, E.; Kim, J.; Xu, M. Environmental, social, and economic implications of global reuse and recycling of personal computers. Environ. Sci. Technol. 2008, 42, 6446-6454.

17. Kahhat, R.; Kim, J.; Xu, M.; Allenby, B.; Williams, E.; Zhang, P. Exploring e-waste management systems in the United States. Resour. Conserv. Recycl. 2008, 52, 955-964.

18. Aoki-Suzuki, C.; Bengtsson, M.; Hotta, Y. Trade of Second-Hand Electric and Electrical Equipments from Japan to Developing Asia: Issues, Policies and its Implication for Extended Producer Responsibility. In Extended Producer Responsibility Policy in East Asia-in Consideration of International Resource Circulation; Hotta, Y., Hayashi, S., Bengtsson, M., Mori, H., Eds.; IGES: Hayama, Japan, 2009.

19. Williams, E. Mandated Prices as an Instrument to Mitigate Environmental Impacts in Informal Reuse/Recycling. In Proceedings of the Second National Institute for Environmental Studies (NIES) Workshop on E-Waste, Tokyo, Japan, November, 2005; pp. 43-56.

20. Keller, M. Assessment of Gold Recovery Processes in Bangalore, India and Evaluation of an Alternative Recycling Path for Printed Wiring Boards, A Case Study; Institute for Spatial and Landscape Planning, Regional Resource Management at the ETH Zurich: Zurich, Switzerland, 2006.

21. Rochat, D.; Hagelüken, C.; Keller, M.; Widmer, R. Optimal Recycling for Printed Wiring Boards (PWBs) in India. In Proceeding of the 2007 Conference on Recovery of Materials and Energy for Resource Efficiency, Davos, Switzerland, 3-5 September 2007.

22. Yu, J.L.; Williams, E.; Ju, M.T.; Shao, C.F. Managing e-waste in China: Policies, pilot projects and alternative approaches. Resour. Conserv. Recycl. 2010, 54, 991-999.

23. Manhart, A. International cooperation for metal recycling from waste electrical and electronic equipment an assessment of the "Best-of-Two-Worlds" approach. J. Ind. Ecol. 2011, 15, 13-30.

24. Wang, F.; Huisman, J.; Meskers, C.E.M.; Schluep, M.; Stevels, A.; Hageluken, C. The best-of-2-worlds philosophy: Developing local dismantling and global infrastructure network for sustainable e-waste treatment in emerging economies. Waste Manag. 2012, 32, 2134-2146.

25. Wang, F.; Kuehr, R.; Ahlquist, D.; Li, J. E-Waste in China: A Country Report; Solve the e-Waste Problem (StEP) Initiative: Bonn, Germany, 2013.

26. Sepulveda, A.; Schluep, M.; Renaud, F.G.; Streicher, M.; Kuehr, R.; Hageluken, C.; Gerecke, A.C. A review of the environmental fate and effects of hazardous substances released from electrical and electronic equipments during recycling: Examples from China and India. Environ. Impact Assess. Rev. 2010, 30, 28-41.

27. Environmental Policy: How to Apply Economic Instrument; OECD: Paris, France, 1991.

28. Managing the Environment: Role of Economic Instruments; OECD: Paris, France, 1994.

29. Kahhat, R. E-waste in Environment and Society. In E-waste Management: From Waste to Resource; Hieronymi, K., Kahhat, R., Williams, E., Eds.; Earthscan: London, UK, 2012.

30. Yu, J.; Williams, E.; Ju, M. Review and Prospects of Recycling Methods for Waste Printed Circuit Boards, Sustainable Systems and Technology, 2009. In Proceedings of the IEEE International Symposium on ISSST'09, Tempe, AZ, USA, 18-20 May 2009; pp. 1-5. 
31. Bator, F.M. The anatomy of market failure. Q. J. Econ. 1958, 72, 351-379.

32. Tohoku Keizai Sangyoukoku. Feasible study on recycle network for precious metals and rare metals from disposed digital home appliance. Tohoku Keizai Sangyoukoku, 2007. (In Japanese).

33. Shirahase, T.; Kida, A. Metals contents in one waste personal computer by detailed dismantling. J. Jpn. Soc. Mater. Cycles Waste Manag. 2009, 20, 217-230 (written in Japanese)

34. Kitco Inc.-Past Historical London Fix. Available online: http://www.kitco.com/ gold.londonfix.html (accessed on 17 July 2013).

35. London Metal Exchange: Historical data. Available online: http://www.lme.com/en-gb/ pricing-and-data/historical-data/ (accessed on 17 July 2013).

36. Japan Oil, Gas and Metals National Corporation. Rare Metals Handbook; Japan Oil, Gas and Metals National Corporation: Tokyo, Japan, 2009.

37. Kojima, M. Institute for Developing Economies, Japan. Personal communication, 2009.

38. Hagelüken, C.; Buchert, M. The Mine above Ground-Opportunities and Challenges to Recover Scarce and Valuable Metals from EOL Electronic Devices; Presentation at the International Electronics Recycling Conference: Salzburg, Austria, 17 January 2008; Available online: http://www.resourcefever.org/publications/presentations/Buchert_Hageluecken.pdf (accessed on 17 July 2013)

39. Fuse, M.; Yamasue, E.; Reck, B.; Graedel, T. Regional development or resource preservation? A perspective from Japanese appliance exports. Ecol. Econ. 2011, 70, 788-797.

40. Salaverry, D. Peru Recicla, Lima, Peru. Personal communication, 2009.

41. Superintendencia Nacional de Aduanas y de Administración Tributaria (SUNAT) (Peruvian trade agency). Online information on Importations. 2010. Available online: www.aduanet.gob.pe (accessed on 1 September 2010).

(C) 2013 by the authors; licensee MDPI, Basel, Switzerland. This article is an open access article distributed under the terms and conditions of the Creative Commons Attribution license (http://creativecommons.org/licenses/by/3.0/). 